\title{
Rational Analysis of Management Accounting Implementation in China's Government Units
}

\begin{abstract}
Xu Jiayu, Lu Yonghua
Xiamen University, Fujian, China

The implementation of management accounting in China's government units is an inevitable requirement of economic development and the important deployment of efficient government establishment. Up to now, China has made a lot of theoretical explorations and tried about management accounting practice in government units. But in practice, there are still some shortcomings. Therefore, based on the thought of Accounting Research Methodology written by Professor Lu Yonghua, this article carries out a comprehensive, systematic, in-depth and concrete study on the implementation of management accounting in China's government units. This paper argues that there are some deficiencies in management accounting practice, including lack of a complete government management accounting system, the failure of combining management accounting implementation with specific national conditions, limitations of government management accounting itself, resistance existing in government management accounting implementation, and the low quality of management accounting practitioners. In this regard, this research paper learns from foreign experience and puts forward some corresponding improvement suggestions from the perspective of legislation, empirical research, information construction, education investment and so on.
\end{abstract}

Keywords: government units, management accounting, Chinese characteristics

\section{The Significance of Implementing Management Accounting in China's Government Units}

Implementing management accounting in China's government units is an inevitable requirement of economic development. In the 1970s, western countries had accumulated a certain degree of capital and some countries had a more mature market economy system. In order to gain a better understanding of the government's fiscal situation and improve government performance and transparency, government management accounting came into being in these countries. It not only improves the government's work, but also promotes the development of all aspects in countries. At present, China's market economy is constantly developing. The evaluation, forecasting, and decision-making work in government units is also increasing in this process. So it is urgent for China's government units to implement management accounting to improve performance and manage government departments better.

It is also an important deployment of efficient government establishment to implement management accounting in China's government units. The 18th Communist Party Congress highlighted the strict control of party to constantly improve the ability of party members to repeal corruption, resist risks, and enhance

Xu Jiayu, Undergraduate, Accounting Department, School of Management, Xiamen University. Email: 839387846@qq.com. Lu Yonghua, Professor, Accounting Department, School of Management, Xiamen University. 
self-purification, self-innovation, and self-improvement. Government management accounting is constructed on the basis of accounting. It is applied with accurate analysis and research to monitor the implementation of budget and determine whether the process is in line with regulations. Meanwhile, the performance appraisal system can also effectively improve the overall quality of government staff and the efficiency of governance to put an end to the bad.

The implementation of management accounting in China's government units can help reduce administrative costs and improve expenditure efficiency. He (2011) found that public sectors are non-profit organizations. Their funds are from public fiscal budget and the fund providers do not require economic returns and profit information. In this resource allocation mechanism, with no need to bear the great economic responsibility, as the unit itself, the staff generally lack cost-effective concept, cost accounting motivation, and cost control motivation. But implementing management accounting in government units can reduce energy consumption effectively, compress costs, and improve asset efficiency and effectiveness. With the internal performance assessment, it can not only improve the transparency of government finance, but also promote government staff's cost-effective awareness and improve expenditure efficiency.

It is because of the positive significance of management accounting implementation to politics, economy, administration, etc. and the existing problems in government management accounting practice in China that carrying out this research has its own great theoretical and practical value.

\section{Literature Review on Management Accounting Practice in Government Units}

\section{Foreign Literature Review}

The concept of government management accounting was first proposed by the American scholar Robson, in his article Management Accounting for Public Administration. He believes that non-profit sectors can apply government management accounting for cost management and performance improvement.

Some scholars think that government units should implement management accounting on the basis of cash. Because cash-based information is narrowed to resources and consumption and delivered information to the great majority of external users. Deaconu, Nistor, and Filip (2011) studied the accrual accounting practice in Romanian government units and found that accrual accounting can better reflect the economic relationship between government unit incomes and costs. This study and international researches show that accrual accounting, a component of a new concept entitled "New Public Management", represents effectiveness, transparency, and accountability. The implementation of accrual-based management accounting can provide a transparent, clear, and pertinent image regarding financial/non-financial performance of public institutions, increase accountability, and improve transparency and the capacity to fairly reflect the patrimony.

The Czech Republic has implemented government unit accounting reform in recent years. Hrůza and Valouch (2016) studied the issue and found that the Czech government has made a number of innovations in the way of government accounting implementation, such as consultation and acceptance, support of the government auditor, comprehensive management training, a robust audit process, etc.. Although there exist some problems in the method reform, it has the learning value and innovation space.

\section{Domestic Literature Review}

Compared with developed countries, China has made less research on management accounting practice in government units. But with the development of social economy, government decision-making requires 
higher-quality accounting information. Zhang (2011) pointed out that government accounting information is an important component of management information and plays a significant role in public management. Management accounting in government units can provide useful information for government managers to make reasonable decisions to achieve government goals, ensure the most reasonable and optimal resource allocation and application, and get access to the best organization's economic and social benefits.

Chinese scholars Pan and Hu (2016) believed that the current priority task is to establish our government management accounting guidance system as soon as possible. The first level is the construction and improvement of law and accounting system, including "Accounting Law", "Budget Law", and supplementary "Administrative Unit Accounting System". The second level is to establish a government management accounting guidance system, including the basic guidelines, application guidelines, and a case library. The third level is the human resource management. Only when China establishes a guidance system in line with national conditions, can government units finish the management accounting implementation in practice.

We believe that the management accounting with Chinese characteristics not only serves the development of Chinese economy, but also is an open and inclusive system in theory and method. In this regard, based on situational theory, Feng (2015) put forward two specific ways: one is situation embedding and the other is situation dependence. Situation embedding applies a certain method in government units with digestion, absorption, and improvement. Situation dependence is the extraction of original management accounting methods from government units and the formation of effective management tools. Research on government management accounting of Chinese characteristics should pay more attention to situation dependence.

In addition, $\mathrm{Hu}, \mathrm{Pan}$, and $\mathrm{Wu}$ (2017) proposed a double integration model for the relationship among government management accounting, government financial accounting, and government budget accounting. It combines the theoretical integration with the application integration. Specifically, it refers to separation in the system, report and measurement basis but requires integration in the accounting processing system, accounting subjects, information system, and human resource. The foundation lies in the full use of large data, cloud accounting modern information technology platform, and the introduction of integrated information research.

\section{The Existing Problems of Management Accounting Implementation in China's Government Units}

China's government units lack a complete government management accounting system. After the reform and opening up, China began to explore the management accounting and it is not long after the beginning of government management accounting study. Nowadays, some China's government units have already piloted management accounting, but it is not implemented in the whole government. The local pilot model leads to low degree of standardization and small scope of government management accounting implementation. Moreover, China has not yet established a complete set of government management accounting system. Because the current research is still limited to the purely theoretical research and lack of in-depth systematic research, different factions have various opinions about the establishment of management accounting system and this causes the lack of a theoretical basis for government management accounting development. Management accounting system, in turn, has a blurred boundary with financial accounting system and it results in the low efficiency. 
Another problem is that the government management accounting practice is not combined with specific national conditions. The current government management accounting does not apply to the development of socialist economy with Chinese characteristics. As China's management accounting system lays too much emphasis on theoretical research, the current government management accounting system does not fit in with practice. At present, most of the government management accounting literature is translated from foreign literature and the application of government management accounting tools also refers to foreign experience. China cannot summarize a set of government management accounting system suitable for the development of socialism economy with Chinese characteristics in the absence of a valid empirical test. This makes our research on government management accounting lag behind economic development needs without innovation and expansibility. Meanwhile, due to the limited understanding of management accounting tools and the perception deviation of application, there exists the phenomenon of blind application in government units and management accounting is unable to play its function and role to the full extent.

Besides, government management accounting has its own limitations. It is mainly reflected by the difficulty of determining and measuring its accounting objects (Shi, 2009). First, the government management accounting objects are public goods and public services provided by government and their accounting is related to not only economic and management issues, but also political and social issues, people's livelihood, etc., making government management accounting objects more complex than business's. Second, the rise of government management accounting is not so long in China and the system is not yet complete. It is difficult to convert objects into data and acquire quantitative data. Third, due to the public nature of government management accounting objects, their cost and income measurement is intervened by other non-governmental factors. This results in its quite complex measurement and the lack of valuable evaluation criteria.

Moreover, there exists a certain resistance in the implementation of government management accounting. Zhang (2011) found that government staff seek for utility maximization as other people in economic activities. As utility is directly related to the size of budget, they aim to maximize their budget. In order to strive for more fiscal budget, on one hand, government staff seek for cost maximization regardless of cost-effectiveness, causing much waste. On the other hand, when preparing the budget, government staff will ignore the change of workload in the sector to strive for more budget. In addition, the limitation of annual budget makes units develop the habit of spending at the end of the year. As a result, government units have no incentive to implement management accounting and even oppose or stop it because of its damage to their vested interests.

What's more, the quality of government management accounting practitioners is not high. As management accounting rises not long ago in China, the formation of the knowledge system is not perfect, resulting in the low professional quality of government management accounting practitioners. Also, with regard to management accounting, the degree of government staff's attention is not high enough, their attitude is not correct and they have not properly recognized the important role and value of equal status between management accounting and financial accounting. In addition, by the impact of traditional ideas, government practitioners believe that accountants only work with accounts and leaders are responsible for management and decision-making, leading to a lack of awareness in providing decision-making information. At the same time, the lack of attention of decision-makers to government management accounting also directly affects the role of management accounting in the decision-making process, so that the data and projects are not paid enough attention, which affects the application of government management accounting. 


\section{Conclusions and Recommendations on Management Accounting Implementation in China's Government Units}

At present, there are still some problems in management accounting implementation in China's government units in aspects of government management accounting system establishment, specific application, the combination of national conditions, resistance in implementation and the quality of personnel. Therefore, combined with the views of domestic and foreign scholars, this article puts forward the following five recommendations.

China needs to speed up legislation and the establishment of government management accounting system. Law guarantees the effective implementation of management accounting in government units. Creating a sound legal environment and defining clear government management accounting duties and works can ensure the smooth application and promotion of management accounting in government units. At present, some government units pilot the implementation of management accounting methods and tools. While providing practical experience, it also causes a narrow range and a lack of normalization. Therefore, establishing a complete management accounting system is beneficial to the unified implementation of management accounting in government units and provides the implementation with a law base.

Based on its national conditions, China should also strengthen empirical research and explore the government management accounting theories and tools suitable for the development of socialism economy with Chinese characteristics. Most of the current management accounting literature is translated from foreign literature. Due to a lack of empirical research, the understanding of government management accounting is not deep enough and there exist blind applications. Therefore, only when government units can strengthen the application of management accounting, apply the theory to practice, find problems from practice, sum up problems, and give feedback to theoretical improvement, can China develop government management accounting theories and tools suitable for China's national conditions. Besides, China must focus on the integration of existing management accounting methods and tools, and strive to develop and innovate management accounting tools with a high level and localization. For example, budgetary reserve pool method was introduced for the phenomenon of bargaining budgets in budget management (Feng, 2011).

Moreover, it is a good way to use accrual government accounting basis. Accrual government accounting can provide more extensive and complex information. It enables government to show fiduciary duties of resource uses, current assets and liabilities, financial changes, etc.. Based on government-provided public goods, public services, and capital investment, we can assess the current government performance. At the same time, accrual basis also helps to solve the disunity between management accounting and financial accounting. In this regard, China can learn from the New Zealand government. It combines management accounting with accrual budget, which effectively promotes the overall reform in New Zealand government and functions well currently.

China also needs to speed up information construction, such as increasing research spending, establishing government ERP system, etc.. Accelerating information construction in government units can simplify the data collection work and provide strong data support for management accounting implementation. At the same time, it can realize resource sharing among government units, which can promote financial transparency and also improve unification and normalization of management accounting implementation in government units. And the establishment of government ERP system can strengthen the establishment, approval, and management of government budget expenditure to promote the efficient use of government resources. 
What's more, China should change the concept of government personnel and increase investment in management accounting education. To effectively change the traditional concept of executive consciousness, China should change government management accounting functions, so that management accounting is no longer limited to accounting and reimbursement, but participate in government decision-making and management to provide efficient and reliable information support for government's strategy. At the same time, China needs to increase spending in government accounting practitioners' education to improve their awareness of participation and their ability of management accounting application as well.

\section{References}

Deaconu, A., Nistor, C. S., \& Filip, C. (2011). The impact of accrual accounting on public sector management: An exploratory study for Romania. Transylvanian Review of Administrative Sciences, 32E, 74-97.

Feng, Q. (2015). Reflections on promoting management accounting with Chinese characteristics. Finance \& Accounting, 22, $11-12$.

Feng, Y. (2011). Improvement and application of budgeting method. Friends of Accounting, 18, 48-51.

He, H. (2011). Discussion on the application of management accounting in public sectors. Economic Research Guide, 26, 113-114.

Hrůza, F., \& Valouch, P. (2016). Public sector accounting policy reform in the Czech Republic: Experience from local governments (pilot). European Financial \& Accounting Journal, 4, 17-37.

Hu, G., Pan, S., \& Wu, C. (2017). Construction of China's government management accounting system under the condition of high efficiency and integrity. Friends of Accounting, 2, 20-25.

Lu, Y. (2003). Accounting research methodology. China Finance Publishing House.

Pan, S., \& Hu, G. (2016). Summary and prospect of government management accounting research. Communication of Finance and Accounting, 16, 39-43.

Shi, L. (2009). The construction and application of government management accounting in China. Chinese \& Foreign Entrepreneurs, 16, 54.

Zhang, Z. (2011). The rise and construction of government management accounting. China Management Informationization, 8 , $8-10$. 